\title{
S. S. Stevens: The psychophysicist
}

\author{
CLIFFORD T. MORGAN \\ University of Texas at Austin, Austin, Texas 78712
}

S. S. Stevens was the way he signed his name to articles and wanted it on the masthead of a journal. His christened name, however, was Stanley Smith Stevens. To his friends and co-workers from the janitor up, he was Smitty. His life, as he wrote in his autobiography, is the story of a man who did not know what he wanted to be until he became it-the world's first Professor of Psychophysics.

Smitty Stevens was born on November 4th, 1906, in Ogden, Utah. Both sides of his family were Mormons. His paternal grandparent, Thomas J. Stevens, was born in Bristol, England, of parents who converted to Mormonism when he was a youngster. At 16, he helped drive the family in a covered wagon from the Missouri River to Utah. His maternal grandfather, Orson Smith, had been born in one of these same covered wagons on the trek of the Mormons to Utah. Thus Stevens grew up a Mormon.

Aside from this fact, nothing unusual marked his childhood days. He recalls that he was very slow to read, and had to take first-grade reading twice before passing it. He was considered listless and low in energy. In high school, however, debating became his passion. In his senior year, he returned from a debating tournament to find his father dying from injuries sustained in an automobile accident. His mother had died of a stroke a few months before. Thus, at 18, he became an orphan and the charge of an uncle.

As many know, Mormons have a practice of sending their young people, usually upon completion of high school, out into the world for a stint of missionary work (in those days, 3 years). In his case, he was assigned to Belgium, where he went knowing no French. By the end of his term, however, he spoke fluent French, a talent of use later at Harvard when Frenchmen or French-speaking scientists came through. In his third year of missionary work, he took a 3-month furlough to Egypt. Palestine, Turkey, the Balkans, and finally Switzerland, where he worked until his release in the summer of 1927 .

He returned to the states in time to enroll as a

This paper in slightly expanded form was presented as the $\mathbf{S}$. S. Stevens Memorial Lecture at the Fourteenth Annual Meeting of the Psychonomic Society in St. Louis on November 1, 1973. It is based on the author's personal contacts with Stevens over the years and on his autobiography which has now appeared in a Festschrift planned before Stevens' death (Moskowitz, Scharf, \& J. C. Stevens, 1974). freshman at the University of Utah. From here on, his training took a path seldom seen in the education of a scientist. He began a hind-end-to education, starting with advanced courses in philosophy, political science, sociology, history, and the like-but no mathematics! Only by the end of the second year did he take psychology, using a text by John B. Watson. Some of Watson rubbed off, because he argued for behaviorism in the Mormon Sunday Classes he taught at Utah and even as late as his graduate days in Cambridge-to the consternation of good Mormons.

After sampling philosophy and social sciences for 2 years at Utah, his uncle packed him off to Stanford to prepare him for law-so the uncle thought-but Smitty still had no idea of what he wanted to do. Finally, going into his senior year, he decided, along with a friend, to do something useful-be a doctor. Toward this end, he enrolled in elementary physics, chemistry, and biology. Applying to Harvard Medical School, he was accepted on the condition that he send $\$ 50$ and take organic chemistry in the summer, neither of which he did.

Instead, not knowing exactly why, he went to the University of Southern California that summer, taking a course in statistics and one in the history of psychology. Then, determined to study something at Harvard, he set out for Cambridge. There he enrolled in the School of Education because its tuition was $\$ 100$ cheaper than in Arts and Sciences. However, only one course in that school, Advanced Statistics, interested him. For two of the others, he found one in physiology with W. J. Crozier and another in psychology (perception) with E. G. Boring.

Before leaving Stanford he had been advised by $C$. P. Stone that it was good practice to ask a professor whether there was some problem he might work on. So he did that with Boring, and Boring promptly put him to work on a problem in color mixing. It was in the course of this work that he suddenly found himself. He became a psychophysicist! As he wrote in his autobiography, "...late one afternoon my scientific career began. There occurred that surge of elation, the Eureka! that drives the investigator. I suddenly sensed that there was a law to be worked out. You could mix some green with the black and white and you could vary the amount in a way that would cancel the effect of a change in distance. A function could be measured! Bursting with elation, I bounded down from the attic that evening and ran all 
the way back [home]." Stevens was to plot functions and look for laws the rest of his life.

That first year at Harvard was the beginning of a phenomenal record. He started thinking of a PhD, wavering between biology and psychology. He chose psychology, apparently because it required no courses, only the passing of preliminary exams. He hadn't done very well on his examination in perception for Boring, but he was told that he could take a crack at the preliminary exams if he wanted to. It was a little more than 3 months until the time of the exams. He calculated that if he mastered 100 pages a day for 100 days, he ought to be able to tell whether experimental psychology would be his thing. He found out. Taking prelims after just two semesters at Harvard while enrolled in the School of Education, he passed his prelims in psychology with flying colors.

On the basis of that performance, he was offered an assistantship in psychology for the following year. $\mathrm{He}$ was said to be one of the worst of assistants because he spent all his time on his own research. By May, he had three papers in press and had applied for his PhD, obtaining it after a hastle over residence just 2 years after his listless undergraduate career. He had turned to hearing, rather than vision, which Boring had started him on, because an oscillator, that great new instrument for making pure tones, was available. His thesis work was on tonal volume, a problem assigned by Boring, but his excitement grew as he discovered a new attribute of tones (density) and found that intensity by itself could change the pitch of a tone-a problem he later got me working on.

After his $\mathrm{PhD}$ came 2 more, amazingly productive years. He was publishing so often he was warned to slow down, lest people think him superficial. The first year was spent on an NRC fellowship, largely at the medical school, where his experiments with Hallowell Davis led to the classic book they authored together. The second year found him a Research Fellow in Physics, where he had already been auditing courses. His fellowship was intended to cover a 3-year interdisciplinary program, but after 1 year, Smitty linally decided that experimental psychology was for him. In the fall of 1935, he took an appointment as instructor in the Department of Psychology at Harvard, a department he was never to leave.

I first saw Stevens on my first attendance at an APA meeting at Dartmouth College in 1936. (With about 800 present, meetings of the APA were then smaller than those of the Psychonomic Society today.) I was alerted to some possible fireworks at a session on hearing where Stevens, and also Wever and Bray, were scheduled to give papers. Indeed, the sparks did fly! Not long before, Wever and Bray had published their paper on the measurement of potentials in the auditory nerve of the cat. The high fidelity of their records (which came to be known as the Wever-Bray effect) made them support a telephone theory of hearing. But Stevens and Davis, repeating the experiments, decided that such high-fidelity potentials must be coming from the cochlea itself. Other experiments of theirs with localized lesions in the cochlea led them to support resonance theory-now the place theory-of pitch perception. So the battle raged. The issue, of course, has since been largely, if not completely, resolved by the brilliant work of von Békésy, whom Stevens later brought to Harvard.

I myself went to Harvard in the fall of 1939. I found Smitty busy both in the laboratory and in his armchair. With Volkmann, he had just finished the revision of his pitch scale. At the same time, his old interest in philosophy had rekindled. This time, the interest was not vague or listless. Rather, he was concerned with the meaning of measurement in science. In a way, he was trying to understand what he was doing when he constructed scales of sensation. His interest was further whetted by the array of philosophers of science who had then congregated at Harvard-Whitehead, Carnap, Birkhoff, and Bridgman. At Smitty's instigation, these men and others held regular monthly meetings on the "Science of Science." Out of these meetings and much solitary thought, Stevens finally got his ideas straight, formulating his hierarchy of scales-nominal, ordinal, interval, and ratio-that are now a bedrock of measurement theory.

In those days at Harvard, it was the custom of the faculty of psychology to gather in the Emerson Hall seminar room for a sandwich lunch. At these lunches, people were supposed to talk seriously about the things going on in their respective heads and laboratories. One day Smitty brought to lunch some preliminary data he and John Volkmann had collected the previous summer. He called them quantum data. He explained that he had earlier come on the idea of a neural quantum in a paper of Békésy`s. Wondering for some time whether Békésy was right, he had started to repeat the experiment. I had been trained in sensory psychology and had seen many psychophysical functions, but never the nice step functions he was showing us. I thought something must be wrong with the experiment. So I started working with Smitty on the experiment, and I became convinced. I am still not sure that there really is a neural quantum, but $I$ am sure the data we collected and later published were good data.

As oldsters will recall, World War II broke out in Europe in the fall of 1939. For a time, the United States was little affected, but after the fall of France in June of 1940, the country began to gird itself for possible war. President Roosevelt released some funds to the National Academy of Sciences to get research started, directing the Armed Services to seek the Academy's help with their problems. Stevens, now recognized as an expert on hearing, was one of the 
first to be consulted. The Air Corps wanted to reduce the noise levels in their airplanes. Stevens recommended that research be undertaken both to measure the effects of noise on human performance and to find effective means of reducing noise. Smitty took the effects of noise on man as his project, and Leo Beranek over in Physics started work on noise reduction. Thus was born the Psycho-Acoustic Laboratory, although it wasn't called that until later. By November 1940, Stevens had found a place to make lots of noise-the basement of Memorial Hall-and was hard at work. He began with himself and one assistant (James P. Egan). By the end of the war, about 50 people were at work in the Psycho-Acoustic Laboratory.

The results of the first project on the effects of noise were largely negative. With all manner of psychomotor and intellectual tests, Stevens' lab was unable to find any significant effects of noise on performance. Noise, it seemed, had only two effects: It interfered with speech communication, and it made people deaf. Stevens' lab then turned to work on the communication problem, while the hearing problem, having medical overtones, was turned over to Hallowell Davis under the aegis of the Committee on Medical Research. Davis pulled me in as his Associate Director, and that is how I came to co-author a monograph on exposure deafness.

When that job was done in early 1943 , I was made a member of the group supervising research at the Psycho-Acoustic Laboratory as well as several other projects.

Stevens' way of running an applied laboratory was certainly different from that of most research administrators. His direction of the many projects that unfolded in his laboratory was, nevertheless, superb. He employed psychologists and other scientists who were first rate at their jobs and gave them a free hand. At the same time, his ideas went into most of what they did, and he kept close tabs on the progress of the work, mostly through conferences each morning with a different research team. He also put his deft editorial hand to virtually every report coming out of the laboratory.

Although World War II ended in the summer of 1945. Stevens was busy well into 1946 , as many of us were, with winding up projects and turning in summary reports. About this time, Harvard decided to split the social and clinical areas from the Department of Psychology and to house the remaining department in the basement of Memorial Hall. This move required the remodeling both of the existing Psycho-Acoustic Laboratory and the unused part of the basement. Smitty spent the better part of 2 years on the remodeling project, overseeing its numerous details. Though he was justly proud of his work, he was frustrated at not getting back to research.

In the meantime, at the urging of Wiley, the publisher of the earlier book by Stevens and Davis, the idea of editing a new Handbook of Experimental Psychology took shape. Smitty was ambivalent about committing his time to such a project, but finally he succumbed. However, because he was still busy with remodeling Memorial Hall, he asked me and E. G. Boring to get things started. So Boring and I worked out the organization of the handbook and the authors to be invited to write for it, checking with Stevens at each stage of the planning.

So it came about that when Stevens finished the remodeling work, he turned to editorial work on the handbook. Smitty was a brilliant editor, turning the dullest of copy into clear, interesting prose. But he was a compulsive editor. He was satisfied with nothing but the best. Consequently, he spent countless hours reworking the million odd words in the handbook. As he later wrote, "Three years ... were squandered on the Handbook of Experimental Psychology." To thousands of students and teachers, however, his work was not squandered, because the handbook served for many years as the single most important reference and text in experimental psychology.

Upon completion of the handbook, Smitty went through something of a depression. For seven years, he had been supervising war research, remodeling Memorial Hall, and editing a handbook. Could he ever get back to doing research of his own? If so, what should he do? What would excite him again the way he had been excited in the thirties? He credits a former student, Wendell R. (Tex) Garner, with arousing him from his lethargy. Garner was finding that loudness scales constructed by the method of equisection and by the method of fractionation did not agree. For one who believed in "laws," Smitty found such confusion intolerable.

Shortly afterward, recognizing that the older psychophysical methods were confounded by procedural effects, he hit on the idea of magnitude estimation-simply assigning numbers to the perceived magnitude of a stimulus. Excitedly collecting data by this method, then trying to figure out how to plot them, he hit upon the "power law." This, as nearly all psychologists know, became the focus of his research for his last 20 years. Not everyone who has worked with the power law is as enthusiastic about it as Stevens was. Nevertheless, the law and the data he collected in support of it certainly form the capstone of his many contributions to psychophysics.

So far, this account has stressed Stevens' roles as scientist, laboratory director, and editor. He also served on many boards and committees. He shied away from elective offices, refusing regularly to run for offices for which he had been nominated. And he tried, espeially in later years, to keep his committee work limited, but he did often serve where he thought he was most needed.

Stevens was also a founder. For years, he agitated for a small society of experimental psychologists that would be free of the professionalism growing in the 
American Psychological Association. When, in 1959, W. S. Verplanck and I thought the time finally ripe for forming such a society, we knew we could call on Stevens to be a founding member of the board of the society. He served us well in the days of our infancy.

Stevens also agitated for a journal devoted to psychophysics, stressing that psychophysics had no publishing home. Psychophysical papers had to be submitted to journals whose principal concern was something else. I proposed to him and to some others who felt the same way about perception that we launch a journal of Perception \& Psychophysics. He was never quite happy with that combination, often urging that we split off psychophysics, but I felt we had to have the combination to develop a successful journal. He went along with that view and was one of the founding members of the editorial board, helping immensely to get the journal off to a good start. Besides conscientious editorial work, he afterward sent virtually every research paper he wrote to Perception \& Psychophysics.

Any tribute to S. S. Stevens, the psychophysicist, would be incomplete without mention of Geraldine "Didi" Stone. Didi later became his wife, but from the time in 1940 when the Psycho-Acoustic Laboratory began to take shape, Didi was Smitty's constant assistant and companion. She lived and worked in the laboratory the same long hours he did. During the war years, she managed the secretaries, the preparation of reports, and many details of laboratory operation. She herself became a superb editor, going over manuscripts before and after Smitty did, and handling details of manuscript preparation such as checking bibliography, reading proof, preparing indexes. When Smitty died, he left a manuscript, now published, which is his opus on psychophysics (Stevens, 1975). Didi saw it through every detail of the publication process. In short, without Didi, Stevens could not have become the psychophysicist that he was.

\section{REFERENCES}

Moskowitz, H. R., Scharf, B., \& Stevens, J. C. (Eds.) Sensation and measurement-Papers in honor of S. S. Stevens. Dordrecht, Holland: Reidel Press, 1974.

Stevens, S. S. In G. Stevens (Ed.), Psychophysics, Introduction to its perceptual, neural and social prospects. New York: Wiley, 1975. 